\title{
How early marriage compromises girls' lives, Maharashtra
}

International Institute for Population Sciences (IIPS)

Follow this and additional works at: https://knowledgecommons.popcouncil.org/departments_sbsr-pgy

Part of the Demography, Population, and Ecology Commons, Family, Life Course, and Society Commons, Gender and Sexuality Commons, International Public Health Commons, Medicine and Health Commons, and the Sociology of Culture Commons How does access to this work benefit you? Let us know!

\section{Recommended Citation}

International Institute for Population Sciences (IIPS). 2008. "How early marriage compromises girls' lives, Maharashtra," Youth in India: Situation and Needs Policy Brief no. 6. Mumbai: IIPS. 


\section{How early marriage compromises girls' lives, Maharashtra}

\author{
THE POLICY AND PROGRAMME \\ DISCOURSE AROUND EARLY MARRIAGE \\ has increased significantly over the last decade \\ in India. For example, several national level \\ policies formulated since 2000, including the \\ National Population Policy 2000, ${ }^{a}$ the National \\ Youth Policy 2003, ${ }^{\text {b }}$ the National Policy for \\ the Empowerment of Women ${ }^{c}$ and, most \\ recently, the Prohibition of Child Marriage \\ Act $2006,{ }^{\mathrm{d}}$ have advocated special programme \\ attention to delay age at marriage and to \\ enforce existing laws against child marriage. \\ Programmatically also, several initiatives, \\ including the Balika Samridhi Yojana, have \\ been launched to prevent early marriage.
}

Despite these commitments, substantial proportions of girls continue to marry in adolescence. As recently as 2005-06, more than two-fifths (47\%) of women aged 20-24 were married by 18 years nationally. While the situation of married young women in India has been increasingly documented, evidence on the ways in which early marriage limits girls' lives and compromises their reproductive health and choices is limited.

This policy brief documents the magnitude of early marriage in Maharashtra and sheds light on the ways in which early marriage compromises young women's lives and reproductive health and choices.

The study

Data are drawn from the Youth in India: Situation and Needs study, a sub-nationally representative study undertaken for the first time in India of key transitions experienced by young people in six states of India. The study included a representative survey of young people in both rural and urban settings. Respondents included unmarried women and men and married women aged 15-24 and, in view of the paucity of married men in these ages, married men aged 15-29.

In Maharashtra, the survey was conducted in 2006. A total of 7,570 married and unmarried young women and men were interviewed in the survey. These included 1,947 married young women, 2,541 unmarried young women, 1,065 married young men and 2,017 unmarried young women.

Early marriage: how common?

Even though the state of Maharashtra is one of the most socially and economically progressive states in the country, Youth Study findings underscore the prevalence of early marriage among young women in the state. Of those aged 20-24, almost one in 10 young women was married before age 15 and over one-third before age 18 . Young women in rural areas were twice as likely as urban young women to be married before age 18; $46 \%$ of rural young women compared to $22 \%$ of urban young women were married before age 18. In contrast, just $2 \%$ of young men aged 20-24 were married before age 18 .

Age at marriage: percentage of young women aged 20-24 who were married before selected ages

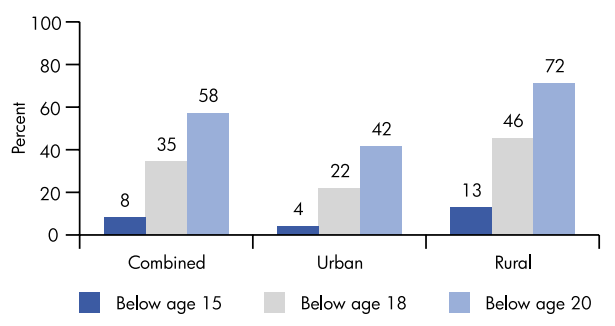

${ }^{a}$ Ministry of Health and Family Welfare. 2000. National Population Policy 2000. New Delhi: Government of India.

b Ministry of Youth Affairs and Sports. 2003. National Youth Policy 2003. New Delhi: Government of India.

c Ministry of Women and Child Development. 2001. National Policy for the Empowerment of Women. New Delhi: Government of India.

d Ministry of Law and Justice. 2007. The Prohibition of Child Marriage Act, 2006, No.6 of 2007, The Gazette of India. New Delhi: Government of India.

e International Institute for Population Sciences (IIPS) and Macro International. 2007. National Family Health Survey (NFHS-3), 2005-06: India, Volume 1. Mumbai: IIPS. 
Of note is the striking difference in the magnitude of early marriage by years of schooling completed by young women. About four in five young women with no formal schooling were married before age 18 . The proportion of young women married before age 18 declined to $33 \%$ among those who had some secondary education and $4 \%$ among those who had completed at least 12 years of schooling. Differences by religion and caste were, in contrast, relatively narrow. example, only $20 \%$ of young women married early, compared to $36 \%$ of those married later, reported that their parents had asked them about their preferred age at marriage. While opportunities for meeting or talking to the spouse-to-be before marriage were limited for all young women, such opportunities were far more limited among those married early. Just $15 \%$ of young women married early, compared to $29 \%$ of those married later, reported that they had ever had a chance to

Magnitude of early marriage: percentage of young women aged 20-24 who were married before age 18, according to years of schooling, religion and caste

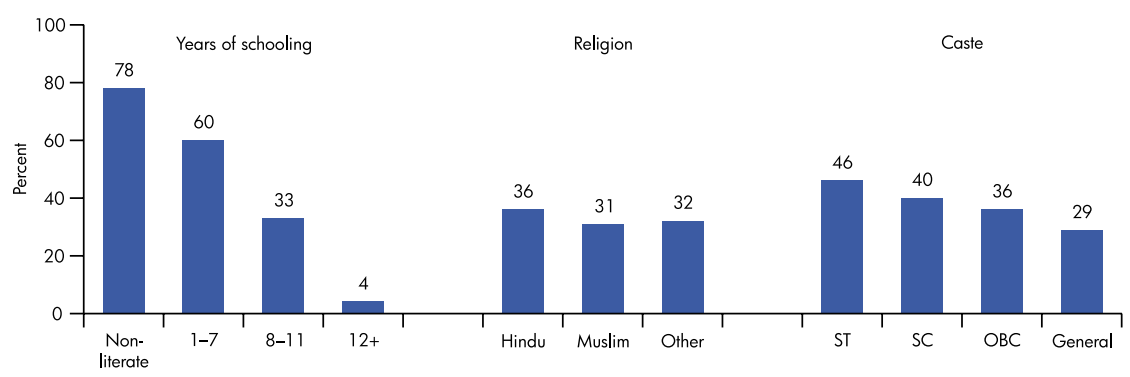

Early marriage: how does it compromise young women's lives and reproductive health and choices?

Findings indicate that early marriage compromises young women's lives and reproductive health and choices in several ways.

\section{Young women's involvement in marriage-related} planning and nature of the marital relationship Compared to young women married at ages 18 and above, young women married early (below age 18) were less likely to have been consulted with respect to the timing of marriage or choice of spouse, and to have received opportunities to develop an acquaintance with their spouse-to-be. For

Young women's involvement in marriagerelated planning

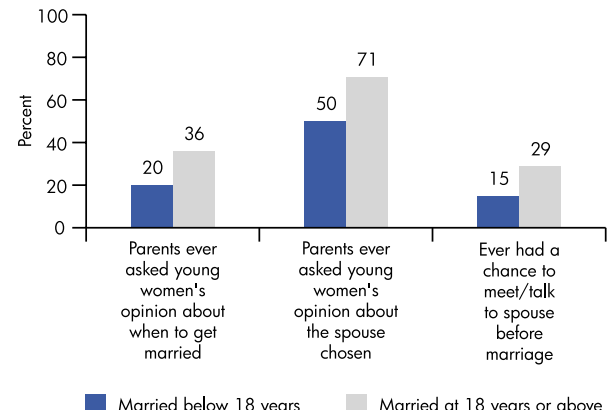

meet and interact with their spouse-to-be alone prior to marriage.

Early marriage also affected the nature of the marital relationship. Findings show that young women married early were less likely than those married later to report close interaction with their husband. For example, just 13\% of young women married early, compared to $26 \%$ of young women married later, reported that they had gone out with their spouse to watch a film in the six months preceding the interview.

Experience of violence within marriage was also more common among those married early. For example, $36 \%$ of those married early, compared to $21 \%$ of those married later,

Nature of the marital relationship: young women's experience of physical and sexual violence within marriage

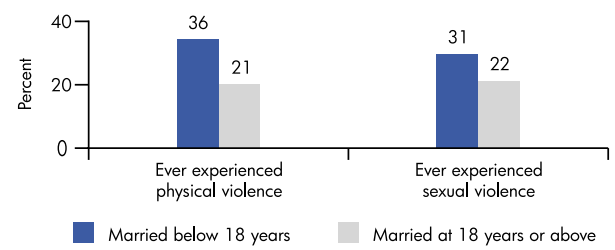

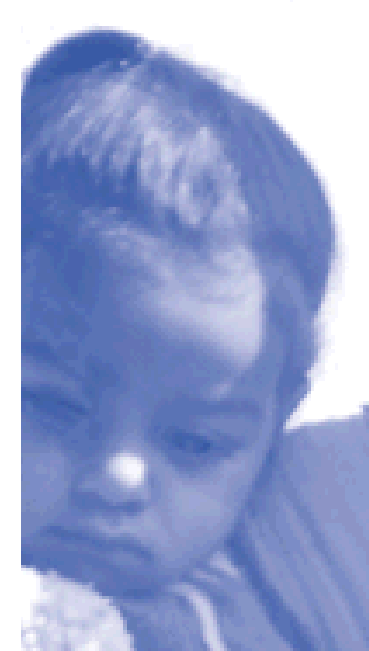

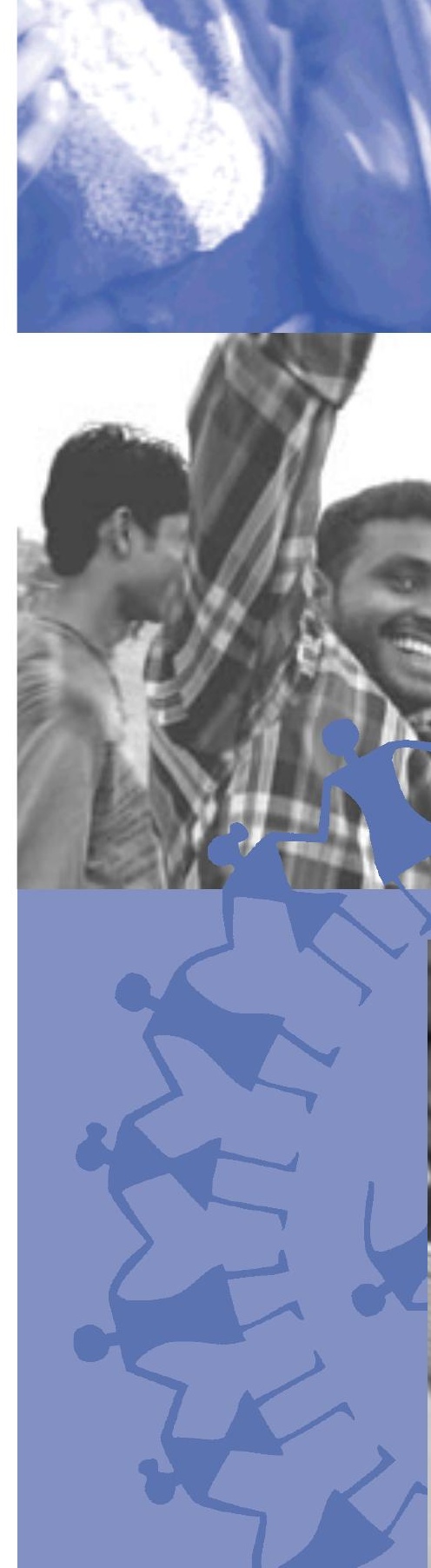


reported having ever experienced physical violence perpetrated by their husband. Similar differences were evident with respect to experiences of sexual violence within marriage.

Young women's decision-making role, self-confidence and gender role attitudes Findings show that early marriage significantly compromised young women's decision-making ability and self-confidence. Young women married early were less likely to have made decisions independently on personal matters such as choosing friends, buying clothes and spending money, than those married later; only $26 \%$ of women married early were able to decide independently on personal matters compared to $40 \%$ of those married later. Similarly, they were less likely to show confidence in expressing their opinion to elders.

\section{Young women's agency and gender role attitudes}

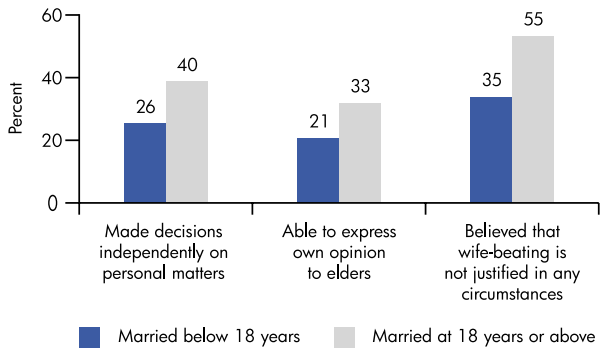

Young women married early were more likely, moreover, to hold gender inegalitarian attitudes, for example with regard to the justifiability of wife-beating. Only $35 \%$ of young women married early, compared to $55 \%$ of those married later, believed that wifebeating is not justified in any circumstances.

Young women's sexual and reproductive health knowledge

Findings also show that young women married early were more likely than those married later to enter marriage uninformed about sexual and reproductive matters. For example, only $8 \%$ of those married early, compared to $27 \%$ of those married later, reported that they were aware of any contraceptive method before marriage. Moreover, young women married early continued to be less informed than those married later about sexual and reproductive health matters even at the time of interview. For example, $70 \%$ of those married early, compared to $79 \%$ of those married later, reported in-depth knowledge of at least one contraceptive method at the time of interview. Likewise, just $28 \%$ of those married early, compared to $46 \%$ of those married later, reported comprehensive awareness of HIV/ AIDS at the time of interview.

Young women's contraceptive and pregnancyrelated experiences

Early marriage also adversely affected young women's contraceptive and pregnancy-related experiences in several ways. For example, use of contraceptives to delay the first pregnancy (6\% versus $15 \%)$ and institutional delivery of the first birth (54\% versus $76 \%$ ) were far less prevalent among those who married early than those who married later. Young women married early were more likely to experience adverse reproductive outcomes compared to those married later. For example, $18 \%$ of those married early, compared to $12 \%$ of those married later, reported having experienced at least one pregnancy loss.

\section{Young women's contraceptive and pregnancy-related experiences}

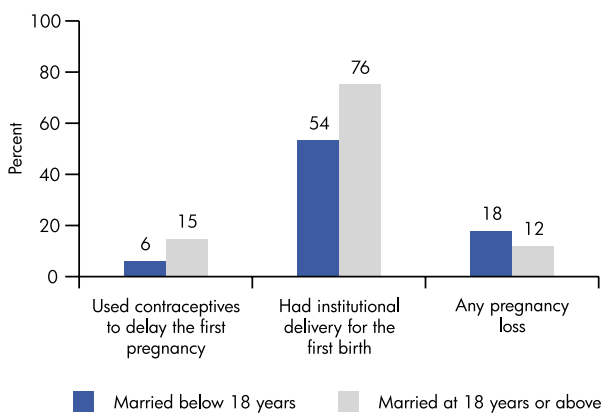

Notably, most of the associations described above remained significant even after controlling for the possible influences of the individual's educational level, work status, place of residence, household economic status, spousal characteristics including spousal age difference and extent of spousal interaction, and parental education. For example, early marriage inhibited young women's involvement in marriage-related planning, their decision-making autonomy and their 
self-efficacy. It placed them at risk of physical and sexual violence within marriage and inhibited them from adopting gender egalitarian attitudes, for example with regard to the justifiability of wife-beating. Finally, women married early were less likely to have experienced institutional delivery and more likely to have experienced pregnancy loss. In contrast, associations observed between early marriage and young women's current knowledge of sexual and reproductive health matters and use of contraceptives to delay the first pregnancy did not remain significant when controlled for other possible influences.

\section{Programme recommendations}

\section{Intensify efforts to eliminate the practice of early marriage}

Efforts need to be multi-pronged: for example, building community support for delayed marriage by involving youth themselves as well as their families; ensuring a greater commitment on the part of law enforcement agencies to enforce existing laws on the minimum age at marriage and the registration of marriages; and at the individual level, ensuring the greater involvement of school, health and other authorities to support young women in negotiating with their parents to delay marriage.

\section{Work with parents}

Parents must be apprised of the need to involve children in marriage-related decisions and enable them to interact with their prospective spouse prior to the wedding day. Parents must also be made aware of the fact that early marriage compromises young women's lives and reproductive health and choices in multiple ways.

\section{Support newly-wed young women}

Findings on the multiple vulnerabilities faced by young women who were married early underscore the need for programmes that support newly-wed young women, acknowledging that their situation and needs may differ from those of married adults. Efforts are needed that address the health and empowerment needs of married young women, enable young women to have greater control over resources, break down their social isolation and encourage couple communication, negotiation and conflict management skills early in marriage. There exist intervention models in India that have attempted to address these needs; these should be reviewed and up-scaled as appropriate so that married young women have the opportunity to exercise control over their lives.

Encouraging signs are evident. Policies and programmes—be they related to women and child development, youth, or health and family welfare-have all recognised the importance of preventing early marriage and improving sexual and reproductive health and choice among young people, including married young women. What is needed now is ensuring that programmes do indeed reach young people and the influential adults in their lives, and that promising lessons are assimilated and scaled up. 